\title{
Molecular detection of Oxyspirura larvae in arthropod intermediate hosts
}

\author{
Sadia Almas ${ }^{1} \cdot$ Anna G. Gibson ${ }^{1} \cdot$ Steven M. Presley ${ }^{1}$ \\ Received: 8 September 2017 / Accepted: 8 January 2018 / Published online: 25 January 2018 \\ (C) The Author(s) 2018. This article is an open access publication
}

\begin{abstract}
To determine potential intermediate hosts of Oxyspirura petrowi, a common nematode eyeworm of wild gallinaceous birds, various arthropod species including red harvester ants, beetles, wood cockroaches, crickets, grasshoppers, katydids, and desert termites were screened for the presence of $O$. petrowi using specific polymerase chain reaction (PCR) primers targeting the internal transcribed spacer 2 region (ITS2) of the eyeworm ribosomal deoxyribonucleic acid (rDNA). This is the first study to investigate the intermediate hosts of $O$. petrowi utilizing molecular techniques. We determined $38 \%$ (13/34) of the cockroaches, $27 \%(3 / 11)$ of the crickets, and $23 \%$ (68/289) of the grasshoppers which were positive for $O$. petrowi. Identifying potential intermediate hosts of $O$. petrowi is essential to better understanding the epizoology of the eyeworm's transmission mechanics and to controlling infections in wild gallinaceous birds.
\end{abstract}

Keywords Oxyspirura petrowi $\cdot$ Intermediate hosts · Galliformes · Parasitic nematodes · Bobwhite quail · Grasshopper · Cockroach

\section{Introduction}

The long-term, and recently (2011-2013) more rapid, decline of northern bobwhite (Colinus virginianus) numbers in the Rolling Plains ecoregion of Texas and Oklahoma was investigated to determine factors that may be influencing their abundance (Fig. 1). During this study, 348 northern bobwhites were screened for different pathogens. Infection rates of $41.4 \%$ of bobwhite collected from individual sites in the Rolling Plains ecoregion by the parasitic nematode eyeworm Oxyspirura petrowi (Spirurida:Thelaziidae) was reported (Dunham et al. 2016).

Typically, these eyeworms are observed on the corneal surface under the nictitating membrane, in nasolacrimal ducts and in conjunctival sacs, causing cellular damage to these tissues; however, their effect on the survivability of their hosts is unknown. (Rodriguez-Tovar et al. 2008; Bruno et al. 2015). Previously, Landgrebe et al. 2007

Steven M. Presley

steve.presley@ttu.edu

1 The Institute of Environmental and Human Health, Texas Tech University, Box 41163, Lubbock, TX 79409-1163, USA reported an $O$. petrowi prevalence of $56 \%$ in scaled quail (Callipepla squamata) surveyed in Texas (Landgrebe et al. 2007). Oxyspirura petrowi is widely geographically distributed and occurs in a wide range of definitive hosts. Oxyspirura petrowi commonly infects wild birds of the order Galliformes in North America and was first reported in Michigan, USA in 1931, and has been reported infecting ruffed grouse (Bonasa umbellus), greater prairie chicken (Tympanuchus cupido), ring-necked pheasant (Phasianus colchicus), and sharp-tailed grouse (Tympanuchus phasianellus) (Cram 1937; Mcclure 1949; Pence 1972; Pence 1975; Pence et al. 1980). Oxyspirura spp. are spiruroid nematodes and include approximately 70 known species, three of which (O. mansoni, O. petrowi, and $O$. pusillae) have been reported in North America (Pence and Sell 1979). Typically these eyeworms are observed on the corneal surface under the nictitating membrane, in nasolacrimal ducts, and in conjunctival sacs, causing cellular damage to these tissues (Rodriguez-Tovar et al. 2008; Bruno et al. 2015).

The life cycle of $O$. petrowi is not well described, but it is assumed to be similar to that of $O$. mansoni, a common eyeworm of poultry. Oxyspirura mansoni requires an intermediate host such as a cockroach (Blattodea) to facilitate transmission to its definitive host. The eyeworm life cycle involves 


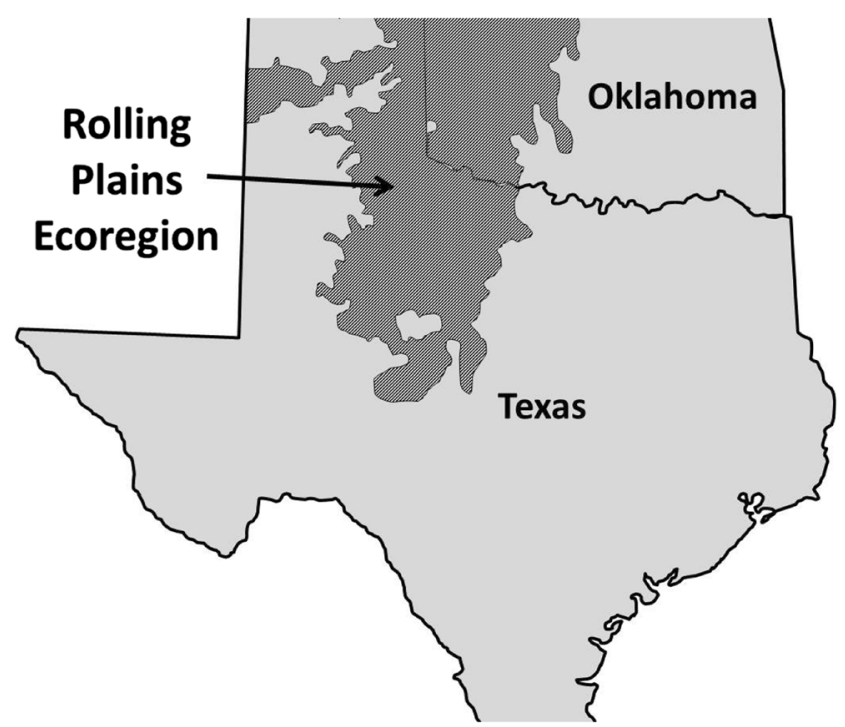

Fig. 1 Map of the geographic area designated as the Rolling Plains ecoregion of Texas and Oklahoma, USA.

50-100 days of stadial progression in the intermediate host, and 48 days in the definitive host (e.g., chicken) (Mcclure 1949). The importance of the intermediate hosts in the life cycle of $O$. mansoni was confirmed after futile attempts to directly infect chickens one to another using embryonated nematode eggs or first-stage eyeworm larvae (Cram 1937). Observational reports suggest various insects such as flies and grasshoppers may serve as intermediate hosts for O. petrowi (Mcclure 1949).

The high prevalence of $O$. petrowi reported in bobwhite and other wild game birds, and the limited knowledge of its transmission mechanisms, necessitate the development of a sensitive, specific, and reliable method to screen different arthropods for the presence of eyeworms. Typically, detection of nematodes in insects involves dissecting the insect and recovering nematodes, then identifying different specimens based on morphological characteristics. This process can be time consuming and its accuracy is highly dependent on the experience of the investigator, as it may be difficult to distinguish between different species of nematodes, especially the larval stages (Perera et al. 2013). We report here the development of a polymerase chain reaction (PCR)-based technique for the detection of any $O$. petrowi life stages in arthropods, for the purpose of learning more about its potential intermediate hosts. This is the first study to identify a range of potential arthropod intermediate hosts of $O$. petrowi based on molecular techniques. Due to their rapid evolution, high variation in their length and nucleotide contents between closely related species, the internal transcribed spacer (ITS) region of the ribosomal nucleic acid (rRNA) gene was chosen as target for developing species-specific primers.

\section{Materials and methods}

This study was conducted in accordance with ethical standards and approved animal care and use protocols (Texas Tech University, Institutional Animal Care and Use Committee protocol No. 11049-070). Eyeworms were collected from the eyes of euthanized bobwhite and stored in $70 \%$ ethanol, then identified initially on the basis of morphological characteristics using a Nikon microscope (TE $2000 \mathrm{U}$ ) at $400 \times$ and $1000 \times$ magnification, after which they were submitted to the U.S. National Parasite Collection for confirmation (USNPC 106874). Deoxyribonucleic acid (DNA) was extracted from single nematode using the DNeasy Blood \& Tissue Kit (QIAGEN, Maryland, USA) according to the manufacturer's instructions. The internal transcribed spacer (ITS) region was amplified using the forward primer SPIR 18 and the reverse primer $28 \mathrm{~S} / 408 \mathrm{R} / 20$ (Ivanova et al. 2007; Makouloutou et al. 2013).The PCR product, $\sim 1200$ base pair (bp), was excised and cloned into JM109 competent cells (Promega Corp., Wisconsin, USA.) according to the manufacturer's instructions. Plasmids were extracted and submitted for genetic sequencing to the University of Maine DNA Sequencing Facility (Orono, Maine, USA). Based on the sequence obtained, the primers $\mathrm{OP}_{3}, 5^{\prime}$ TGTTGTGGAGCAGT TAAAATCC-3', and $\mathrm{OP}_{4}, 5^{\prime}$ AACGTTATTGTTGCCATATG CT-3', were designed to amplify a 197-bp region of ITS2.

To ensure specificity, the intraspecific variation in the ITS region of this genus was investigated. The sequence of the ITS1 region of $O$. petrow $i$ was aligned with the corresponding region of $O$. conjunctivalis, which was the only Oxyspirura spp. with a sequence available in the National Center for Biotechnology Information (NCBI) database (accession number EF417873). Primers were synthesized by Integrated DNA Technologies, Inc. (IDT) (Iowa, USA). PCR conditions included a 2-minute denaturation step at $94{ }^{\circ} \mathrm{C}$, followed by 35 cycles of $94{ }^{\circ} \mathrm{C}$ for $30 \mathrm{~s}, 55^{\circ} \mathrm{C}$ for $30 \mathrm{~s}$, and $72{ }^{\circ} \mathrm{C}$ for $1 \mathrm{~min}$, with a final elongation step at $72{ }^{\circ} \mathrm{C}$ for $10 \mathrm{~min}$. The specificity of primers was verified using the Basic Local Alignment Search Tool (BLAST) against the NCBI database. To further confirm the specificity of the primers, DNA isolated from the nematode Strongyloides stercoralis was used as a negative control. To determine the sensitivity of the primers, PCR was performed with $100 \mathrm{ng}-1 \mathrm{pg}$ of template DNA from O. petrowi.

Arthropod specimens were collected during biannual trapping of quail during the months of August and October (2012 and 2013) from several ranches across the Rolling Plains ecoregion of Texas and western Oklahoma. Various insects, including red harvester ants (Order: Hymenoptera), beetles 
(Order: Coleoptera), wood cockroaches (Order: Blattodea), crickets (Order: Orthoptera), grasshoppers (Order: Orthoptera), katydids (Order: Orthoptera), and desert termites (Order: Isoptera) were collected in close proximity to bobwhite quail trapping sites using baited petri plates, insect sweep nets, commercially available pheromone traps, and bread- and beer-baited traps as described by Pechal and others (Pechal et al. 2007). Collected specimens were preserved in $70 \%$ ethanol and stored at $-20{ }^{\circ} \mathrm{C}$ until analysis. Arthropods were identified to the lowest taxonomic level possible using morphological keys (Capinera et al. 2005) (Arnet 2000). Arthropods that could not be identified based on morphological characteristics were identified by direct sequencing of their amplified DNA and comparison to known sequences by BLAST analysis against the NCBI database (Folmer et al. 1994). Arthropods preserved in ethanol were dried overnight at room temperature, and thoroughly washed using distilled water. Individual grasshoppers, crickets, cockroaches, and beetles were kept separate for screening, while red harvester ants and desert termites were pooled by species $(\leq 20$ specimens/pool) based on trapping locations. Screening of arthropods for the presence of O.petrowi was accomplished by extracting DNA from individual and pooled specimens using the DNeasy Blood \& Tissue Kit (QIAGEN, Maryland, USA). Specimens were then analyzed for the presence of eyeworms using the $O$. petrowi-specific primers (OP3/OP4) designed to the ITS2 region, as described above. Primers were sensitive enough to detect $1 \mathrm{pg}$ genomic DNA of $O$. petrowi. To ensure the reliability and validity of the PCR assay, negative and positive controls containing DNA of Strongyloides stercoralis and $O$. petrowi were run along with the samples, respectively. To further validate results, amplified PCR products from ten positive samples were cloned into JM109 competent cells according to the manufacturer's (Promega Corp., Wisconsin, USA) instructions, then submitted for genetic sequencing to the University of Maine DNA Sequencing Facility (Orono, Maine, USA).

\section{Results}

Primers SPIR 18F and 28S/408R/20 amplified the entire ITS region, including a partial $18 \mathrm{~S}$, ITS1, 5.8S, ITS2, and a partial 28S. The sequence was deposited into the NCBI database with accession number KF 306222 to make it publicly accessible. The designed primers to the ITS2 region were very effective $(100 \%)$ in amplifying the target region of $O$. petrowi.

Total arthropod samples included 6 beetles, 11 crickets, 22 katydids, 34 cockroaches, 289 grasshoppers, 34-pooled samples of desert termites, and 134 pooled samples of red harvester ants. Of the arthropods determined to be positive for O. petrowi by PCR, $38 \%$ (13/34) of the cockroaches, $27 \%$ $(3 / 11)$ of the crickets, and $23 \%(68 / 289)$ of the grasshoppers were determined to contain DNA of $O$. petrowi. All of the red ants, beetles, katydids, and termites were determined to be negative for the eyeworm. Out of the 15 different species of grasshoppers screened for the presence of $O$. petrowi, six different species of grasshoppers including Melanoplus differentialis, Melanoplus femurrubrum, Trimerotropis pallidipennis, Melanoplus ponderosus, Opeia obscura, and Hippiscus ocelote were positive for $O$. petrowi. Other than these grasshopper species, Texas field cricket (Gryllus texensis) and wood cockroach (Parcoblatta spp.) were also

Table 1 Oxyspirura petrowi infection rates in various Blattodea and Orthoptera arthropod species collected from the Rolling Plains ecoregion of Texas and Oklahoma

\begin{tabular}{|c|c|c|}
\hline $\begin{array}{l}\text { Arthropod species } \\
\text { screened }\end{array}$ & Common name & $\begin{array}{l}\text { Percentage positive } \\
\text { for } O \text {. petrowi }\end{array}$ \\
\hline $\begin{array}{l}\text { Melanoplus } \\
\quad \text { differentialis }^{\mathrm{a}}\end{array}$ & Differential grasshopper & $40 \%(14 / 35)$ \\
\hline Parcoblatta spp. ${ }^{\mathrm{b}}$ & Wood cockroach & $38 \%(13 / 34)$ \\
\hline $\begin{array}{l}\text { Melanoplus } \\
\quad \text { femurrubrum }^{\mathrm{a}}\end{array}$ & Red-legged grasshopper & $32 \%(10 / 31)$ \\
\hline $\begin{array}{l}\text { Trimerotropis } \\
\text { pallidipennis }{ }^{\mathrm{a}}\end{array}$ & $\begin{array}{l}\text { Pallid-winged } \\
\text { grasshopper }\end{array}$ & $32 \%(9 / 28)$ \\
\hline $\begin{array}{l}\text { Melanoplus } \\
\text { ponderosus }^{\mathrm{a}}\end{array}$ & Spur-throated grasshopper & $31 \%(19 / 62)$ \\
\hline Opeia obscura ${ }^{\mathrm{a}}$ & Obscure grasshopper & $31 \%(4 / 13)$ \\
\hline Gryllus texensis $^{\mathrm{c}}$ & Texas field cricket & $27 \%(3 / 11)$ \\
\hline Hippiscus ocelote ${ }^{\mathrm{a}}$ & Wrinkled grasshopper & $16 \%(12 / 73)$ \\
\hline Syrbula montezuma ${ }^{\mathrm{a}}$ & Montezuma's grasshopper & $0 \%(0 / 1)$ \\
\hline Leprus wheeleri $^{\mathrm{a}}$ & $\begin{array}{l}\text { Wheeler's blue-winged } \\
\text { grasshopper }\end{array}$ & $0 \%(0 / 1)$ \\
\hline $\begin{array}{l}\text { Hesperotettix viridis } \\
\text { pratensis }^{\mathrm{a}}\end{array}$ & $\begin{array}{l}\text { Purple-striped } \\
\text { grasshopper }\end{array}$ & $0 \%(0 / 3)$ \\
\hline Boopedon nubilum ${ }^{\mathrm{a}}$ & Ebony grasshopper & $0 \%(0 / 4)$ \\
\hline Boopedon gracile & $\begin{array}{l}\text { Graceful range } \\
\text { grasshopper }\end{array}$ & $0 \%(0 / 5)$ \\
\hline $\begin{array}{l}\text { Hadrotettix } \\
\quad \text { trifasciatus }^{\mathrm{a}}\end{array}$ & $\begin{array}{l}\text { Three-banded } \\
\text { grasshopper }\end{array}$ & $0 \%(0 / 5)$ \\
\hline Brachystola magna $^{\mathrm{a}}$ & Plains lubber grasshopper & $0 \%(0 / 8)$ \\
\hline Schistocerca obscura ${ }^{\mathrm{a}}$ & Obscure bird grasshopper & $0 \%(0 / 10)$ \\
\hline $\begin{array}{l}\text { Campylacantha } \\
\text { olivacea }^{\mathrm{a}}\end{array}$ & $\begin{array}{l}\text { Fuzzy olive-green grass- } \\
\text { hopper }\end{array}$ & $0 \%(0 / 10)$ \\
\hline $\begin{array}{l}\text { Pediodectes } \\
\text { haldemani }^{\mathrm{d}}\end{array}$ & $\begin{array}{l}\text { Haldeman's shieldback } \\
\text { katydid }\end{array}$ & $0 \%(0 / 22)$ \\
\hline $\begin{array}{l}\text { Pogonomyrmex } \\
\text { barbatus }^{\mathrm{e}}\end{array}$ & Red harvester ants & $\begin{array}{l}0 \%(0 / 134) \text { pooled } \\
\text { samples }\end{array}$ \\
\hline $\begin{array}{l}\text { Gnathamitermes } \\
\text { tubiformans }\end{array}$ & Desert termites & $\begin{array}{l}0 \%(0 / 34) \text { pooled } \\
\text { samples }\end{array}$ \\
\hline Unknown & Beetles & $0 \%(0 / 6)$ \\
\hline \multicolumn{3}{|l|}{${ }^{\mathrm{a}}$ Orthoptera: Acrididae } \\
\hline \multicolumn{3}{|l|}{${ }^{\mathrm{b}}$ Blattodea: Ectobiidae } \\
\hline \multicolumn{3}{|l|}{${ }^{\mathrm{c}}$ Orthoptera: Gryllidae } \\
\hline \multicolumn{3}{|c|}{${ }^{\mathrm{d}}$ Orthoptera: Tettigoniidae } \\
\hline \multicolumn{3}{|c|}{${ }^{\mathrm{e}}$ Hymenoptera: Formicidae } \\
\hline${ }^{\mathrm{f}}$ Blattodea: Termitidae & & \\
\hline
\end{tabular}


determined to contain DNA of eyeworm (Table 1). To validate our results, the DNA of ten different specimens that were PCR-positive were cloned and sent for sequencing. Complete identity of ITS2 region of adult nematode with ITS2 rDNA sequence of these larval samples not only confirmed our results but also demonstrated the similarity of the sequences of larvae and adults.

\section{Discussion}

The objective for this project was to develop a PCR-based method to identify potential intermediate arthropod hosts for O. petrowi. Our efforts consisted of amplifying the ITS $1 / 5.8 \mathrm{~S} /$ ITS2 region of ribosomal DNA (rDNA) of the nematode and designing primers to target its ITS2 region. To the best of our knowledge, there is no method reported for the screening of arthropods for the presence of $O$. petrowi other than the traditional method of visual inspection. The desired approach towards designing primers specific for $O$. petrowi would have included sequence alignment of all congeners that were sympatric, which in this case would have been $O$. pusillae, because $O$. petrowi and $O$. pusillae have been reported to occur in the same areas (Pence 1972). Further, it would have been beneficial to understand the level of intraspecific variation at this locus for this group of parasites, but the lack of sequence data for $O$. pusillae and O. mansoni in the NCBI database and lack of access to worms of these species for PCR made this unfeasible. However, even if the sequence obtained from an arthropod showed $100 \%$ identity with the sequence of O. petrowi, without the proper knowledge of the intraspecific variation within this genus, it is difficult to conclude that the insect was indeed infected with $O$. petrowi and not some other species of this genus that is prevalent in that locality. Arguments posed by Pence with respect to the occurrence of $O$. petrowi and $O$. pusillae in different ecological niches, as well as the identification of all adult worms collected in this study as $O$. petrowi, strongly suggest that $O$. petrowi is the only species of Oxyspirura prevalent in the study areas (Pence 1972).

To validate our primers, we compared the ITS1 region of $O$. petrowi with the ITS1 sequence of the only species of Oxyspirura present in the NCBI database, O. conjunctivalis. A comparison of the ITS2 regions were not possible because there are no sequence data for the ITS2 region of $O$. conjunctivalis, nor for any species taxonomically related to the eyeworms of the genus Thelazia, in the NCBI database. The ITS1 regions of the Oxyspirura species showed very few similarities, indicating the rapid evolution of the ITS region in spiruroid nematodes (Ivanova et al. 2007). Thus, because of the sufficient level of variation, this region was considered capable of being used to discriminate between species of the same genus. Additionally, the ITS region had been proven to be a reliable genetic marker for the identification of Thelazia spp. in arthropods serving as intermediate hosts (Traversa et al. 2005). Grasshoppers were abundantly available in the study areas and were the insect commonly found in the crops of quail, and they constituted the major portion of the arthropod specimens collected (Jackson 1969).

Our findings identified different species of arthropods that may be serving as the intermediate host of $O$. petrowi in this ecoregion. Because these arthropods can harbor and transmit many other parasites, a molecular analysis based on the ITS2 region was performed to specifically identify $O$. petrowi. The presence of $O$. petrowi in a variety of insects illustrates its general behavior at the intermediate host level, and its potential to invade a variety of insects. This wide range of potential intermediate hosts and its numerous definitive hosts makes the survival of $O$. petrowi possible over a large geographical range.

Acknowledgments The authors acknowledge and appreciate funding support for this study from the Rolling Plains Quail Research Foundation. The authors thank Eric Hoberg and Patricia Pilitt of the U.S. National Parasite Collection for providing the authoritative identification of specimens attributed to $O$. petrowi. The authors also thank the participating ranch owners in the Rolling Plains ecoregion for their collaboration.

\section{Compliance with ethical standards}

Conflict of interest The authors declare that they have no conflicts of interest.

Open Access This article is distributed under the terms of the Creative Commons Attribution 4.0 International License (http:// creativecommons.org/licenses/by/4.0/), which permits unrestricted use, distribution, and reproduction in any medium, provided you give appropriate credit to the original author(s) and the source, provide a link to the Creative Commons license, and indicate if changes were made.

\section{References}

Arnet RH (2000) American insects: a handbook of the insects of America North of Mexico: second edition. CRC Press LLC, Boca Raton 1024 pp

Bruno A, Fedynich AM, Smith-Herron A, Rollins D (2015) Pathological response of northern bobwhites to Oxyspirura petrowi infections. J Parasitol 101(3):364-368. https://doi.org/10.1645/14-526.1

Capinera JL, Scott RD, Walker TJ (2005) Field guide to grasshoppers, katydids, and crickets of the United States. Cornell University Press, Ithaca $280 \mathrm{pp}$

Cram EB (1937) A review of the genus Oxyspirura, with a morphological study of $O$. petrowi Skrjabin, 1929, recently discovered in galliform birds of the Northern United States. Pap Helminthol 89-98

Dunham NR, Bruno A, Almas S, Rollins D, Fedynich AM, Presley SM, Kendall RJ (2016) Eyeworms (Oxyspirura petrowi) in northern bobwhites (Colinus virginianus) from the rolling plains ecoregion of Texas and Oklahoma, 2011- 13. J Wildl Dis 52(3):562-567. https://doi.org/10.7589/2015-04-103 
Folmer O, Black M, Hoeh W, Lutz R, Vrijenhoek R (1994) DNA primers for amplification of mitochondrial cytochrome $\mathrm{c}$ oxidase subunit I from diverse metazoan invertebrates. Mol Mar Biol Biotechnol 3: 294-299

Ivanova E, Spiridonov S, Bain O (2007) Ocular oxyspirurosis of primates in zoos: intermediate host, worm morphology, and probable origin of the infection in the Moscow zoo. Parasite 14:287-298

Jackson AS (1969) A handbook for bobwhite quail management in the west Texas Rolling Plains. Bulletin number 48. Texas Parks and Wildlife Department, Austin

Landgrebe JN, Vasquez B, Bradley RG, Fedynich AM, Lerich SP, Kinsella JM (2007) Helminth community of scaled quail (Callipepla squamata) from western Texas. J Parasitol 93(1):204 208. https://doi.org/10.1645/GE-3578RN.1

Makouloutou P, Setsuda A, Yokoyama M, Tsuji T, Saita E, Torii H, Kaneshiro Y, Sasaki M, Maeda K, Une Y, Hasegawa H (2013) Genetic variation of Gongylonema pulchrum from wild animals and cattle in Japan based on ribosomal RNA and mitochondrial cytochrome c oxidase subun. J Helminthol 87:326-335

Mcclure HE (1949) The eyeworm, Oxyspirura petrowi, in Nebraska pheasant. J Wildl Manag 13(3):304-307. https://doi.org/10.2307/ 3795873

Pechal JL, Austin J, Gold R, Tomberlin JK (2007) Epidemiology and spatial relationships of bacteria associated with Periplaneta americana (Blattodea: Blattidae) in Central Texas. J Agric Urban
Entomol 24(4):205-216. https://doi.org/10.3954/1523-5475-24.4. 205

Pence DB (1972) The genus Oxyspirura ( Nematoda : Thelaziidae ) from birds in Louisiana. Proc Helminthol Soc Wash 39:23-27

Pence DB (1975) Eyeworms (Nematoda : Thelaziidae) from West Texas quail. Proc Helm Soc Wash 42:181-183

Pence DB, Sell DL (1979) Helminths of the lesser prairie chicken, Tympanuchus pallidicintus (Ridgway) (Tetraonidae), from the Texas panhandle. Proc Helminthol Soc Wash 46:146-149

Pence DB, Young V, Guthery F (1980) Helminths of the ring-necked pheasant Phasianus colchicus (Gmelin) (Phasianidae), from the Texas panhandle. Proc Helminthol Soc Wash 47:144-147

Perera A, Maia JP, Jorge F, Harris DJ (2013) Molecular screening of nematodes in lacertid lizards from the Iberian peninsula and Balearic Islands using 18S rRNA sequences. J Helminthol 87(02): 189-194. https://doi.org/10.1017/S0022149X12000181

Rodriguez-Tovar LE, Casas-Martínez A, Ramírez-Romero R, NevárezGarza AM, Zarate-Ramos JJ (2008) First report of Oxyspirura sp. from a captive fulvous owl (Strix fulvescens) in Mexico. J Parasitol 94(6):1430-1431. https://doi.org/10.1645/GE-1599.1

Traversa D, Otranto D, Iorio R, Giangaspero A (2005) Molecular characterization of Thelazia lacrymalis (Nematoda, Spirurida) affecting equids: a tool for vector identification. Mol Cell Probes 19(4):245249. https://doi.org/10.1016/j.mcp.2005.01.005 